\title{
Acute hypokalaemic quadriparesis in dengue fever
}

\author{
Amitava Roy, Anil Kumar Tripathi, Shailendra Prasad Verma, Himanshu Reddy, Nirdesh Jain
}

Internal Medicine, CSM Medical University, Lucknow, Uttar Pradesh, India

Correspondence to Dr Amitava Roy, amitleena.roy@gmail.com

\section{Summary}

The authors report acute hypokalaemic quadriparesis in two young patients that occurred during dengue epidemic in 2010 in India. Both patients developed flexic type of pure motor weakness in all four limbs without bladder bowel involvement, following 2 to 3 days of fever and malaise. Higher mental functions were normal. Serum potassium level was very low; 2-2.5 m mol/l. Non-structural protein (NS ${ }_{1}$ )-antigen and immunoglobulin M-antibody for dengue were positive in both patients. Both patients improved with potassium supplementation. In follow-up, they are doing well.

\section{BACKGROUND}

Acute hypokalaemic quadriparesis is an uncommon presentation of dengue fever, not yet widely recognised. Only few cases are reported from different institutes world wide. Awareness of this condition will enable physicians to keep a possibility of hypokalaemia in patients of dengue fever presenting with paresis and to manage specifically and effectively.

\section{CASE PRESENTATION}

\section{Case 1}

A 29-year-old male was hospitalised with complaints of high grade fever and malaise for 2 days and paralysis of all four limbs for 1 day. He was taking paracetamol for fever. History of any other drug intake could not be elicited. He was unmarried, non-vegetarian and had no addiction. He was febrile $\left(39.4^{\circ} \mathrm{C}\right)$, ill looking but conscious and has no icterus, rash, generalized oedema and lymphadenopathy. Vitals were normal. Neurological examination revealed normal cranial nerves. He had power of grade $2 / 5$ in all four limbs with inability to hold his neck. There was a generalised hyporeflexia and hypotonia. Plantar were bilateral non-elicitable. There were no sensory, bladder or bowel involvement. Family history was insignificant.

\section{Case 2}

A 24-year-male was hospitalised with complaints of mild fever, headache and body ache for 2 days and acute onset weakness of all limbs for 1 day. He took paracetamol for fever. He was not married, a non-vegetarian and had no addictions. His vitals were stable and general examination revealed motor power $3 / 5$ in all limbs. Deep-tendon reflexes were diminished and planter was non-elicitable, examination of sensory system and cranial nerve was normal.

\section{INVESTIGATIONS}

Case 1

serum potassium: $2.0 \mathrm{mmol} / \mathrm{l}$, serum sodium: $138 \mathrm{mmol} / \mathrm{l}$, serum calcium(ionic): $5.07 \mathrm{mg} / \mathrm{dl}$, serum magnesium: 2.1 $\mathrm{mg} / \mathrm{dl}$, serum creatine kinase: $165 \mathrm{U} / \mathrm{l}$. Non-structural protein $\left(\mathrm{NS}_{1}\right)$ antigen and immunoglobulin $\mathrm{M}$ (IgM)-dengue positive, haemoglobin: $14.7 \mathrm{gm} \%$, haematocrit: 43.2 , platelet count: 1.3 lakhs $/ \mathrm{mm}^{3}$. Urine potassium level: $32 \mathrm{mmol} /$ day. Liver, renal and thyroid profiles were normal.

\section{Case 2}

serum potassium: $2.3 \mathrm{mmol} / \mathrm{l}$, serum sodium: $138 \mathrm{mmol} / \mathrm{l}$, serum calcium(ionic): $4.17 \mathrm{mg} / \mathrm{dl}$, serum magnesium: 2.2 $\mathrm{mg} / \mathrm{dl}$, serum creatine kinase: $172 \mathrm{U} / 1 \mathrm{NS}_{1}$ antigen and IgM dengue positive, haemoglobin: $14.0 \mathrm{~g} / \mathrm{dl} \%$, haematocrit: 42.0, platelet count $67000 / \mathrm{mm}^{3}$. Urine potassium level: 50 $\mathrm{mmol} /$ day. Liver, renal and thyroid profiles were normal.

\section{DIFFERENTIAL DIAGNOSIS}

- Acute flaccid quadriparesis in early phase of myelitis

- Channelopathies

- Acute Guillain-Barré syndrome (GB) syndrome

- Compressive myelopathy in spinal shock.

\section{TREATMENT}

\section{Case 1}

Intravenous-potassium chloride infusion was given. By day 2 , the power in all four limbs improved. His serum potassium improved to $5.3 \mathrm{mg} / \mathrm{dl}$ at day 4 . He was discharged with advice to take potassium rich diet.

\section{Case 2}

Patient was managed conservatively with potassium supplements orally. Patient started recovering within $12 \mathrm{~h}$ of treatment and discharged after 3 days.

\section{OUTCOME AND FOLLOW-UP}

Both patients improved and were discharged with advice to take potassium rich diet. In follow-up after 1 week, both patients were asymptomatic and are doing well.

\section{DISCUSSION}

Neurological manifestations of dengue fever include encephalitis, encephalopathy, aseptic meningitis, mononeuropathies, polyneuropathies, GB syndrome, myelitis, 


\section{BMJ Case Reports}

intracranial haemorrhage and thrombosis. The pathology of neurological manifestation is multiple and includes neurotropic effect of dengue virus, systemic effect of dengue infection and immune-mediated injury. ${ }^{1}$ Jha and Ansari ${ }^{2}$ reported three confirmed cases of dengue infection causing acute reversible-hypokalaemic pure motor quadriparesis. Gupta et a $\beta$ reported two confirmed cases of hypokalaemic periodic paralysis precipitated by upper respiratory tract infection of viral aetiology. They also observed that potassium supplementation resulted in rapid improvement of symptoms. Santos et al ${ }^{4}$ reported GB syndrome in the course of dengue. The clinical profile of dengue is changing, and the neurological manifestations are reported more frequently. Widodo et at observed prevalence of hypokalaemia in $23 \%(n=105)$ of the hospitalised patients with infectious disease and Kalita et al studied 16 patients with dengue fever with quadriparesis, in seven, the pure motor quadriparesis was due to myositis. ${ }^{6}$ Hypokalaemia in association with infectious diseases, particularly in dengue fever, has been reported. Hypokalaemic paralysis secondary to chikungunya fever has also been documented. The putative mechanism of the hypokalaemia in our patients could be either due to redistribution of potassium in cells or transient renal tubular abnormalities, leading to increased urinary potassium wasting. Preliminary investigations were not suggestive of renal tubular abnormality. However, transient self limiting renal tubular defects secondary to infection could not be ruled out. Stress induced surge of catecholamine and insulin may result in intracellular shift of potassium and hypokalaemia.

\section{Learning points}

- Hypokalaemic quadriparesis is an unusual presentation of dengue.

- Short duration of fever precedes the symptoms of quadriparesis.

- Quadriparesis improved rapidly after the supplementation of potassium.

- Bony pain typical of dengue fever was not present.

\section{Competing interests None.}

Patient consent Obtained.

\section{REFERENCES}

1. Pancharoen C, Thisyakorn U. Neurological manifestations in dengue patients. Southeast Asian J Trop Med Public Health 2001;32:341-5.

2. Jha $\mathbf{S}$, Ansari MK. Dengue infection causing acute hypokalemic quadriparesis. Neurol India 2010;58:592-4.

3. Gupta M, Lehl SS, Singh R, et al. Hypokalemic periodic paralysis;2 novel causes. Internet J Neurol 2009;12:1.

4. Santos NO, Azoubel AC, Lopes AA, et al. Guillain-Barré syndrome in the course of dengue: case report. Arq Neuropsiquiatr 2004;62:144-6.

5. Widodo D, Setiawan B, Chen K, et al. The prevalence of hypokalemia in hospitalized patients with infectious diseases problem at Cipto Mangunkusumo Hospital, Jakarta. Acta Med Indones 2006;38:202-5.

6. Kalita J, Misra UK, Mahadevan A, et al. Acute pure motor quadriplegia: is it dengue myositis? Electromyogr Clin Neurophysio/ 2005;45:357-61.

7. Rampal, Sharda M, Meena H. Hypokalemic paralysis following Chikungunya fever. J Asso Physicians India 2007;55:598.

This pdf has been created automatically from the final edited text and images.

Copyright 2011 BMJ Publishing Group. All rights reserved. For permission to reuse any of this content visit http://group.bmi.com/group/rights-licensing/permissions.

BMJ Case Report Fellows may re-use this article for personal use and teaching without any further permission.

Please cite this article as follows (you will need to access the article online to obtain the date of publication).

Roy A, Tripathi AK, Verma SP, Reddy H, Jain N. Acute hypokalaemic quadriparesis in dengue fever. BMJ Case Reports 2011; 10.1136/bcr.11.2010.3514, date of publication

Become a Fellow of BMJ Case Reports today and you can:

- Submit as many cases as you like

- Enjoy fast sympathetic peer review and rapid publication of accepted articles

- Access all the published articles

- Re-use any of the published material for personal use and teaching without further permission

For information on Institutional Fellowships contact consortiasales@bmjgroup.com

Visit casereports.bmj.com for more articles like this and to become a Fellow 